\section{SOI: 1.1/TAS DOI: 10.15863/TAS International Scientific Journal Theoretical \& Applied Science}

p-ISSN: 2308-4944 (print)

e-ISSN: 2409-0085 (online)

Year: 2017

Issue: 05

Volume: 49

Published: $27.05 .2017 \quad$ http://T-Science.org
Denis Chemezov

Master of Engineering and Technology, Corresponding Member of International Academy of Theoretical and Applied Sciences, Lecturer of Vladimir Industrial College, Russian Federation chemezov-da@yandex.ru

SECTION 6. Metallurgy and energy.

\title{
STRESS FIELDS IN A STEEL CASTING
}

Abstract: The article are presented the calculated stress fields and displacements arising in the cooling process (solidification) of the steel ingot in the mould.

Key words: a casting, stress, solidification, deformation.

Language: English

Citation: Chemezov D (2017) STRESS FIELDS IN A STEEL CASTING. ISJ Theoretical \& Applied Science, 05 (49): 165-172.

Soi: http://s-o-i.org/1.1/TAS-05-49-25 Doi: crossef https://dx.doi.org/10.15863/TAS.2017.05.49.25

\section{Introduction}

$25 \%$ of all castings in engineering are making of steel. Using a modern equipment and the special moulding technologies [1] with the subsequent necessary thermal treatment, it is possible to obtain the complex configurations of the steel castings with the high mechanical properties.

Due to the low castability of steel (this is caused by the high viscosity and the surface tension in the liquid state), solidification of the casting occurs uneven throughout the volume. This process is especially pronounced in the thick-walled steel castings. It promotes the formation of hot tears and internal stresses in the casting material [2]. In conjunction with the other defects (change of the shape and the linear dimensions), the casting will be considered defective [3].

Since cast occurs in a closed mould without the possibility of a tracking process, then a mathematical calculation in the special computer programs allows with high accuracy to obtain a complete picture of the mould filling by melt, cooling of an alloy and to make the analysis of the hidden defects after solidification of the low carbon steel casting of the simple configuration.

\section{Materials and methods}

The calculation of the stress-strain state of the steel casting during cooling was performed according to the elasto-plastic model in the computer program LVMFlow [4]. As the casting it was taken an ingot from chrome-manganese steel of the grade $16 \mathrm{MnCr} 5$ of length $100 \mathrm{~mm}$, width $50 \mathrm{~mm}$ and height $50 \mathrm{~mm}$.
Steel contains $0.15 \%$ carbon, $0.45 \%$ silicon, $0.9 \%$ manganese, $0.15 \%$ chromium, $0.03 \%$ phosphorus, $0.03 \%$ sulfur, $0.23 \%$ copper, $0.01 \%$ nickel, $0.05 \%$ molybdenum and $98 \%$ iron. The liquidus temperature [5] for the alloy is $1512.221{ }^{\circ} \mathrm{C}$, the solidus temperature is $1476.787{ }^{\circ} \mathrm{C}$, the eutectic temperature [6] is $1142.306{ }^{\circ} \mathrm{C}, \mathrm{CLF}$ up (the proportion of the liquid phase in which the formed crystals freely flow together with melt) is $70 \%$, CLF down (the proportion of the liquid phase below which there is no stream in the absence of plastic deformation) is $70 \%$, compressibility (parameter which is depended from the material properties, for example, the content of gas in melt) is $301 / \mathrm{Mbar}$, CLFpres. (the parameter which equal to CLF down multiplied by 0.8 ) is $56 \%$, CLF Niyama (the criterion which is used for the prediction of shrinkage porosity in the casting material) is $3 \%$, the specific heat of crystallization is $172.6 \mathrm{~kJ} / \mathrm{kg}$ and the specific heat of formation of the eutectic is 130 $\mathrm{kJ} / \mathrm{kg}$.

The temperature data for Young's modulus and Poisson's ratio for steel of the grade $16 \mathrm{MnCr} 5$ are linearly extrapolated by the temperature points introduced in the solid phase until the liquidus temperature. The cooling process is characterized by the increased value of Young's modulus and shear modulus of the material casting. At a temperature of $22{ }^{\circ} \mathrm{C}$ the value of Young's modulus of steel is 211 $\mathrm{GPa}$, bulk modulus is $164 \mathrm{GPa}$, shear modulus is 82 $\mathrm{GPa}$ and Poisson's ratio is 0.285 . The mechanical properties of chrome-manganese steel at the change temperature are presented in Fig. $1-4$. 


\begin{tabular}{l|lrl|l|ll} 
& ISRA (India) & $=\mathbf{1 . 3 4 4}$ & SIS (USA) & $=\mathbf{0 . 9 1 2}$ & ICV (Poland) & $=\mathbf{6 . 6 3 0}$ \\
Impact Factor: & ISI (Dubai, UAE) $=\mathbf{0 . 8 2 9}$ & PUHU (Russia) $=\mathbf{0 . 2 3 4}$ & PIF (India) & $=\mathbf{1 . 9 4 0}$ \\
& GIF (Australia) & $\mathbf{0 . 5 6 4}$ & ESJI (KZ) & $=\mathbf{3 . 8 6 0}$ & IBI (India) & $\mathbf{4 . 2 6 0}$
\end{tabular}

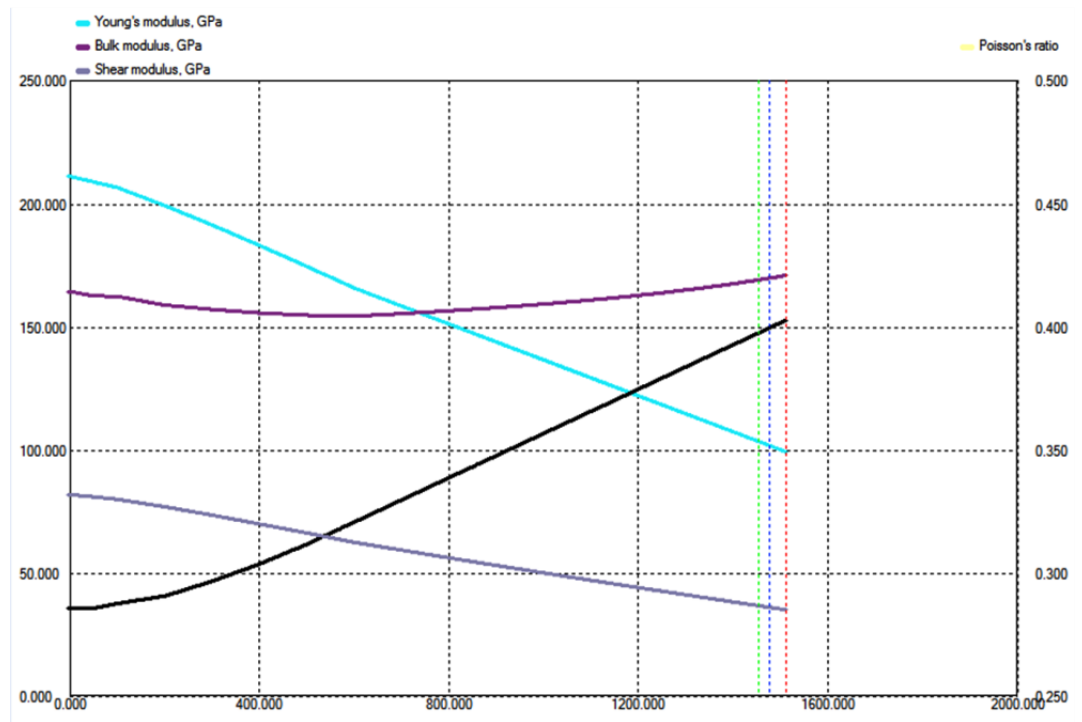

Figure 1 - The dependencies of Young's modulus, bulk modulus, shear modulus and Poisson's ratio of steel of the grade $16 \mathrm{MnCr} 5$ from the temperature.

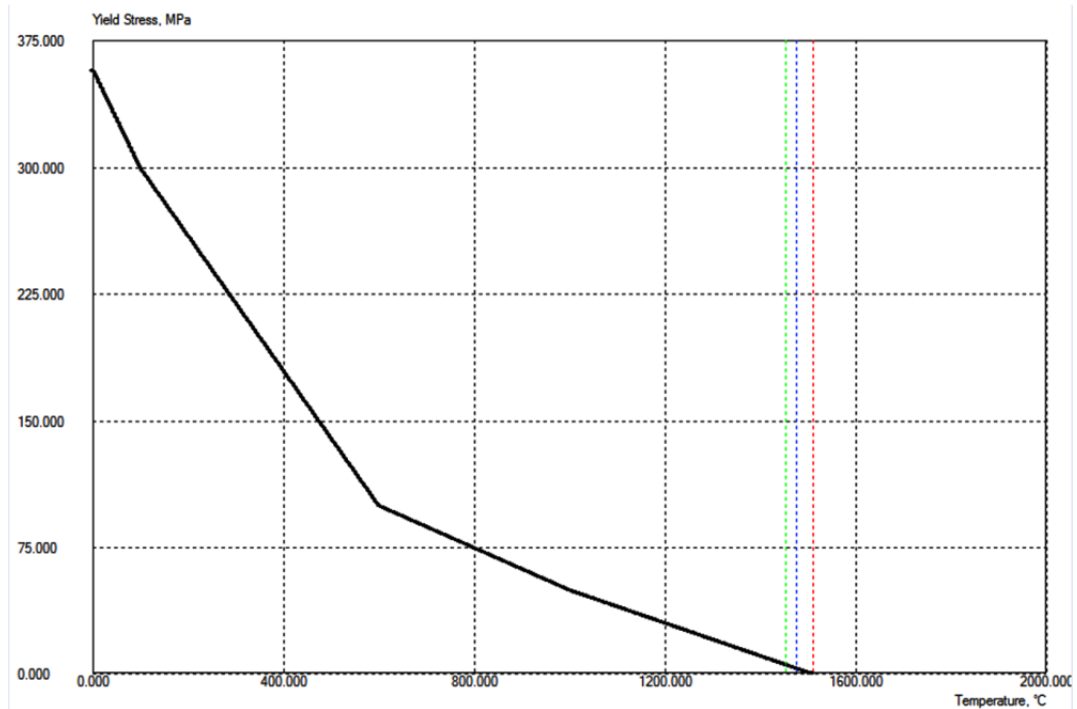

Figure 2 - The dependence of yield stress of steel of the grade $16 \mathrm{MnCr} 5$ from the temperature.

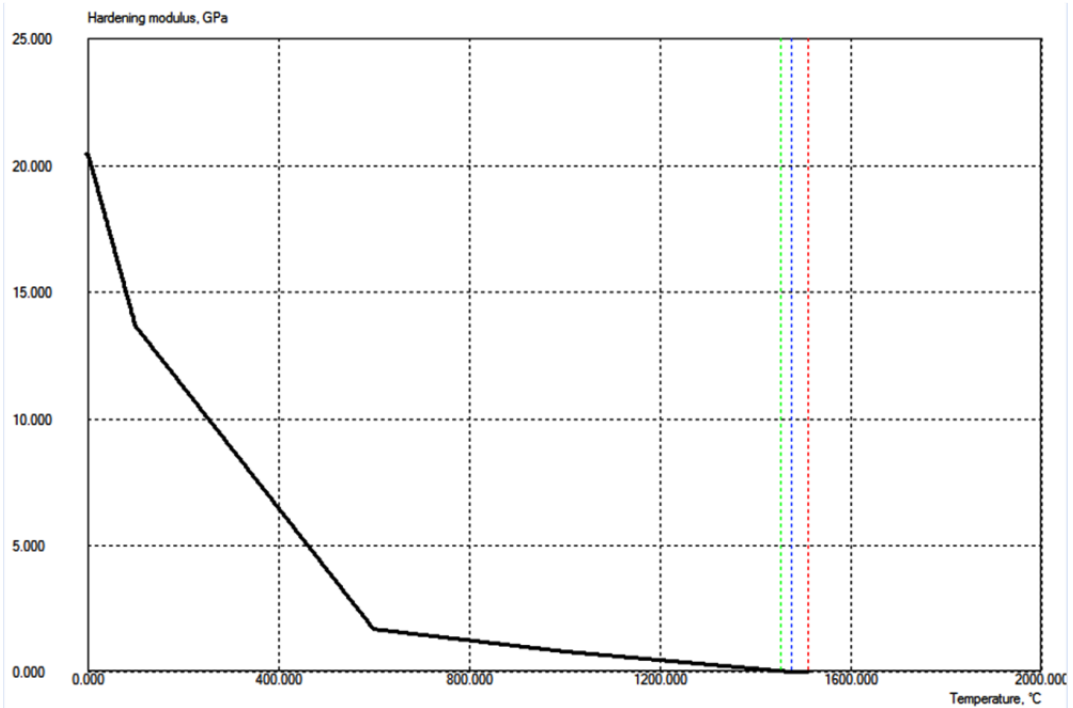

Figure 3 - The dependence of hardening modulus of steel of the grade $16 \mathrm{MnCr} 5$ from the temperature.

ISPC Technology and progress,

Philadelphia, USA 


\begin{tabular}{l|lrl|l|ll} 
& ISRA (India) & $=\mathbf{1 . 3 4 4}$ & SIS (USA) & $=\mathbf{0 . 9 1 2}$ & ICV (Poland) & $=\mathbf{6 . 6 3 0}$ \\
Impact Factor: & ISI (Dubai, UAE) $=\mathbf{0 . 8 2 9}$ & PUHU (Russia) $=\mathbf{0 . 2 3 4}$ & PIF (India) & $=\mathbf{1 . 9 4 0}$ \\
& GIF (Australia) & $\mathbf{0 . 5 6 4}$ & ESJI (KZ) & $=\mathbf{3 . 8 6 0}$ & IBI (India) & $\mathbf{4 . 2 6 0}$
\end{tabular}

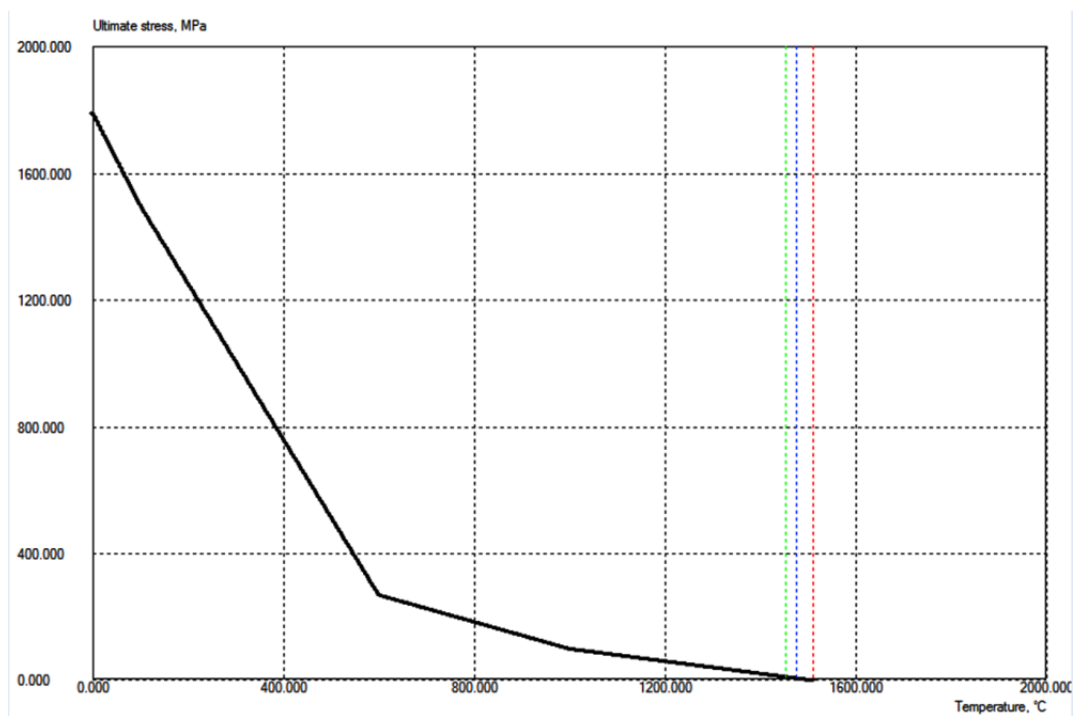

Figure 4 - The dependence of ultimate stress of steel of the grade $16 \mathrm{MnCr} 5$ from the temperature.

In the temperature range $600-22{ }^{\circ} \mathrm{C}$ a rapid increase of yield stress, ultimate stress and hardening modulus of steel is occurred [7]. The black line on the chart (Fig. 1) is the dependence of Poisson's ratio from the temperature.

Steel has a high heat conduction, which decreases with the increasing temperature. The alloy density in the liquid and solid phases decreases with the increasing temperature.
The simulation is consisted in the mould filling of melt at the initial temperature of $1610{ }^{\circ} \mathrm{C}$ and subsequent cooling (solidification) of the casting. Mould was a model, which is simulated the casting process. The internal cavity of the mould was a shape of the casting after solidification. The flow of melt into the mould was carried out through the feeder.

The diagram of the casting process of the steel ingot is presented in Fig. 5.

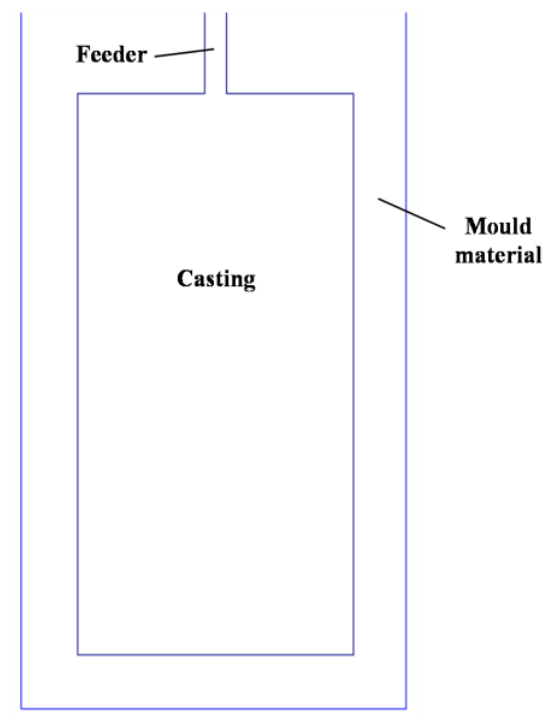

Figure 5 - Problem statement.

The maximum calculation step for solidification of the casting is adopted of $64.65 \mathrm{~s}$.

\section{Results and discussion}

The calculated solidification time of the casting amounts to $261.039 \mathrm{~s}$. The temperature of the casting after the process simulation of solidification amounts to $180.031{ }^{\circ} \mathrm{C}$.

The following calculated fields were obtained:
1. The resultant displacement of the casting from the initial position.

2. Maximal principal stress in the casting material (i.e. the most principal value of the stress tensor) represents maximum stress of a normal uniaxial tension at the point of a solid body.

3. Median principal stress in the casting material, i.e. the average principal value of the stress tensor. 


\begin{tabular}{|c|c|c|c|c|c|c|}
\hline Impact Factor: & $\begin{array}{l}\text { ISRA (India) } \\
\text { ISI (Dubai, UAF } \\
\text { GIF (Australia) } \\
\text { JIF }\end{array}$ & $\begin{array}{l}=1.344 \\
=0.829 \\
=0.564 \\
=1.500\end{array}$ & $\begin{array}{l}\text { SIS (USA) } \\
\text { PИНЦ (Russia } \\
\text { ESJI (KZ) } \\
\text { SJIF (Morocco }\end{array}$ & $\begin{array}{l}=\mathbf{0 . 9 1 2} \\
=\mathbf{0 . 2 3 4} \\
=\mathbf{3 . 8 6 0} \\
=\mathbf{2 . 0 3 1}\end{array}$ & $\begin{array}{l}\text { ICV (Poland) } \\
\text { PIF (India) } \\
\text { IBI (India) }\end{array}$ & $\begin{array}{l}=6.630 \\
=1.940 \\
=4.260\end{array}$ \\
\hline
\end{tabular}

4. Minimal principal stress in the casting material. Stress acts perpendicular to the plane on which shear stress equals zero.

5. Yield stress in the casting material represents yield stress in the conditions of the uniaxial tension at the solidus temperature.

6. Von Mises stress in the casting material. The parameter characterizes the value of shear stresses in the solid body.

7. Pressure in the casting material. The parameter characterizes the isotropic part of tensile stresses in the solid body.

8. Effective plastic strain of the casting, i.e. the value of the tensor accumulated plastic strain at the point of the solid body.

9. The plastic deforming work represents the volume density of work stresses by the plastic deforming of the point of the solid body.
10. Hot tears in the casting material. The threshold value for the formation of hot tears in the material.

The calculated fields of the stress-strain state of the casting material after solidification are presented in Fig. 6 - 15.

The inner layers of the casting material are cooled down in the last turn, therefore they are exposed to highest deformations and stresses. This is caused by the change of the specific volume alloy with the change of the temperature. The simultaneous tensile and compression of the alloy leads to the combined inhibition of shrinkage. As the result a discontinuity of the casting material occurs.

In the case when there is no exceeding of ultimate stress of the material, internal stresses remain, leading in the process of operation to the change of the shape and dimensions of the casting.

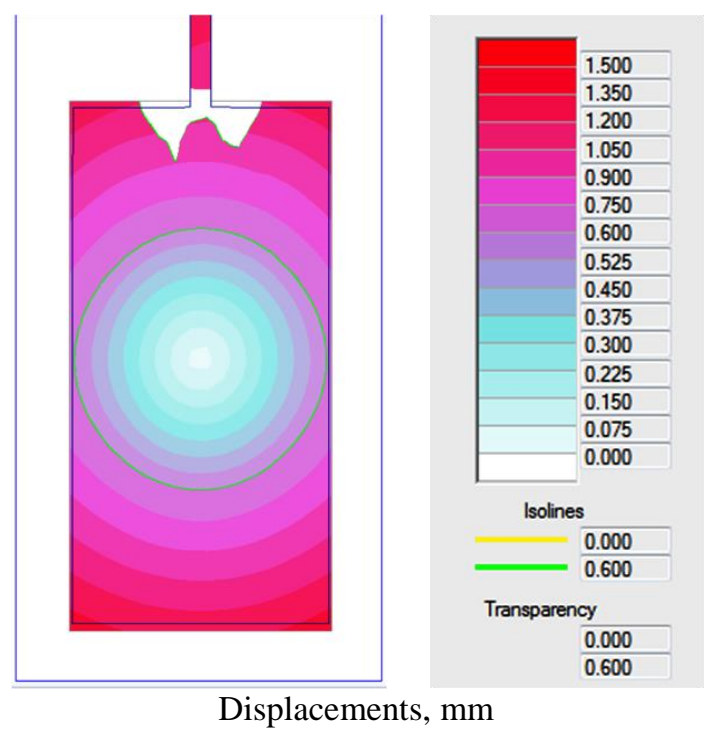

Figure 6 - Displacements in the casting on 261.039 second of the solidification process.
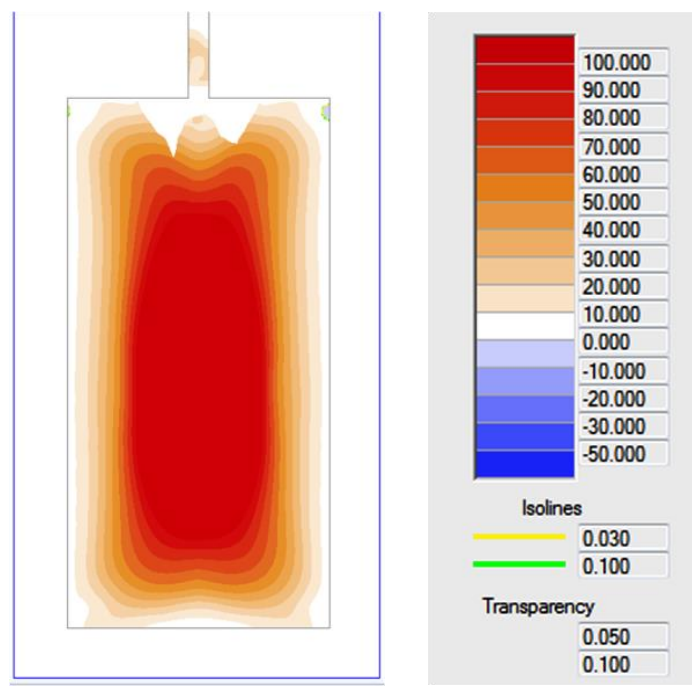

Maximal principal stress, MPa

Figure 7 - Maximal principal stress in the casting on 261.039 second of the solidification process. 


\begin{tabular}{l|lrl|l|ll} 
& ISRA (India) & $=\mathbf{1 . 3 4 4}$ & SIS (USA) & $=\mathbf{0 . 9 1 2}$ & ICV (Poland) & $=\mathbf{6 . 6 3 0}$ \\
Impact Factor: & ISI (Dubai, UAE) $=\mathbf{0 . 8 2 9}$ & PUHU (Russia) $=\mathbf{0 . 2 3 4}$ & PIF (India) & $=\mathbf{1 . 9 4 0}$ \\
& GIF (Australia) & $\mathbf{0 . 5 6 4}$ & ESJI (KZ) & $=\mathbf{3 . 8 6 0}$ & IBI (India) & $\mathbf{4 . 2 6 0}$
\end{tabular}

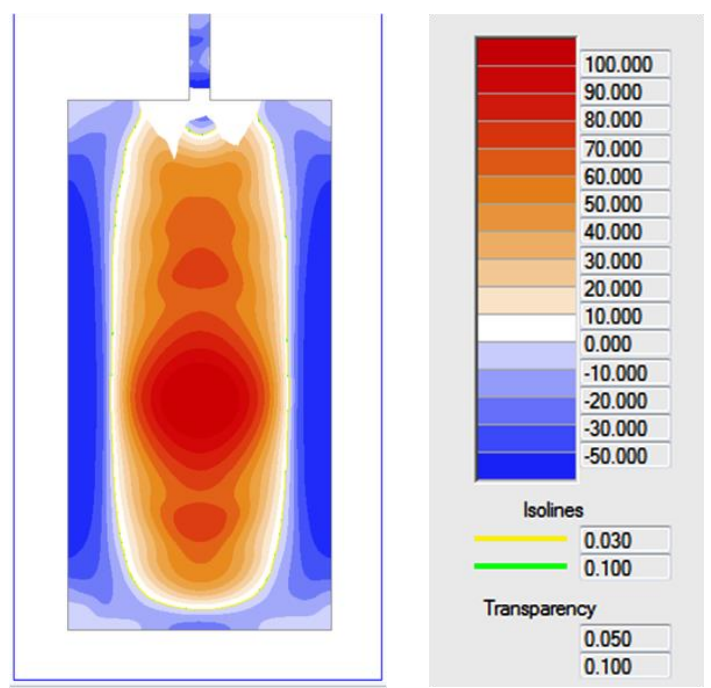

Median principal stress, MPa

Figure 8 - Median principal stress in the casting on 261.039 second of the solidification process.
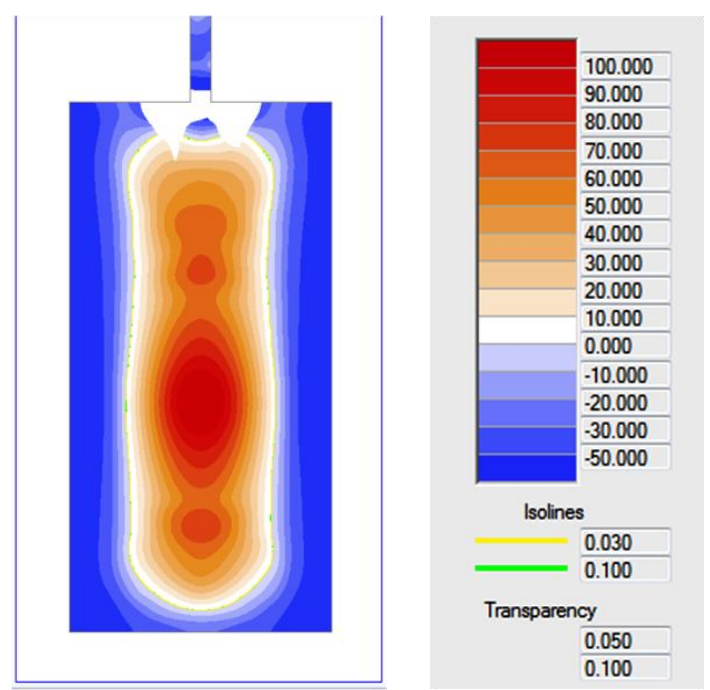

Minimal principal stress, MPa

Figure 9 - Minimal principal stress in the casting on 261.039 second of the solidification process.
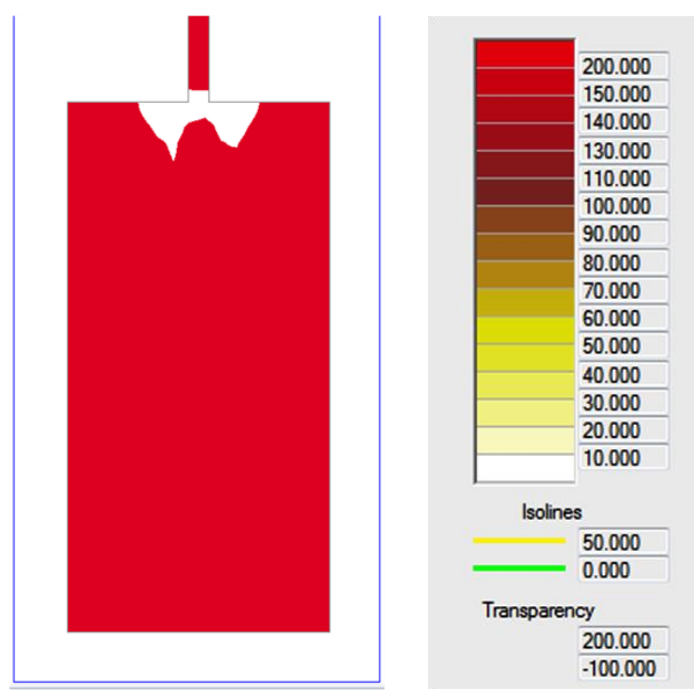

Yield stress, MPa

Figure 10 - Yield stress in the casting on 261.039 second of the solidification process. 


\begin{tabular}{l|lrl|l|ll} 
& ISRA (India) & $=\mathbf{1 . 3 4 4}$ & SIS (USA) & $=\mathbf{0 . 9 1 2}$ & ICV (Poland) & $=\mathbf{6 . 6 3 0}$ \\
Impact Factor: & ISI (Dubai, UAE) $=\mathbf{0 . 8 2 9}$ & PUHU (Russia) $=\mathbf{0 . 2 3 4}$ & PIF (India) & $=\mathbf{1 . 9 4 0}$ \\
& GIF (Australia) & $\mathbf{0 . 5 6 4}$ & ESJI (KZ) & $=\mathbf{3 . 8 6 0}$ & IBI (India) & $\mathbf{4 . 2 6 0}$
\end{tabular}
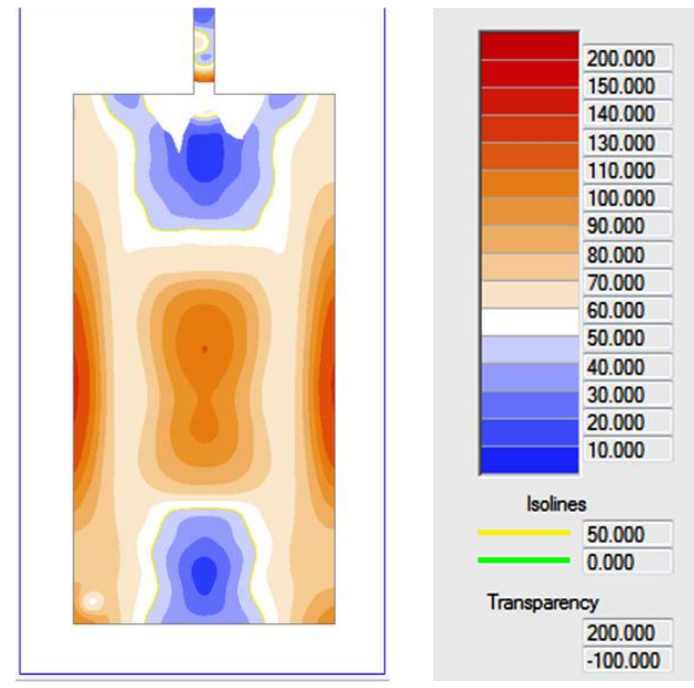

Von Mises stress, MPa

Figure 11 - Von Mises stress in the casting on 261.039 second of the solidification process.
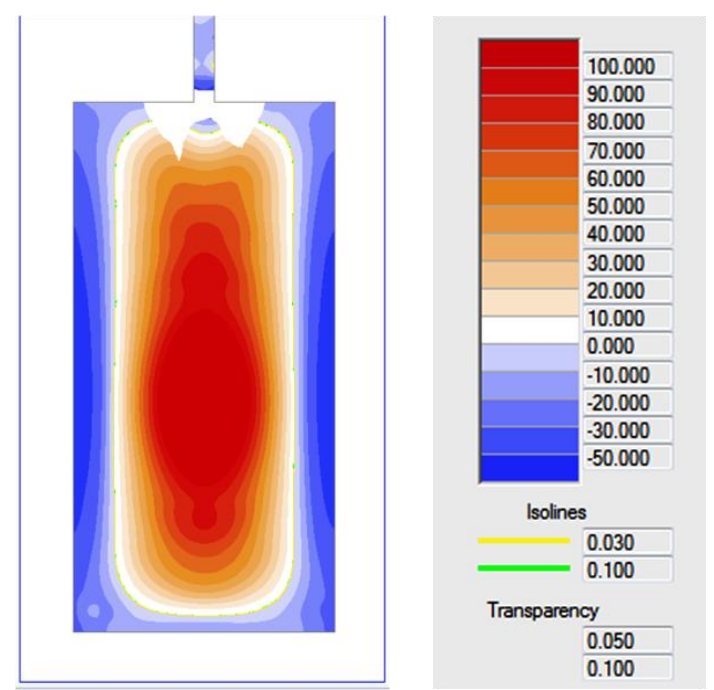

Pressure, $\mathrm{MPa}$

Figure 12 - Pressure in the casting on 261.039 second of the solidification process.
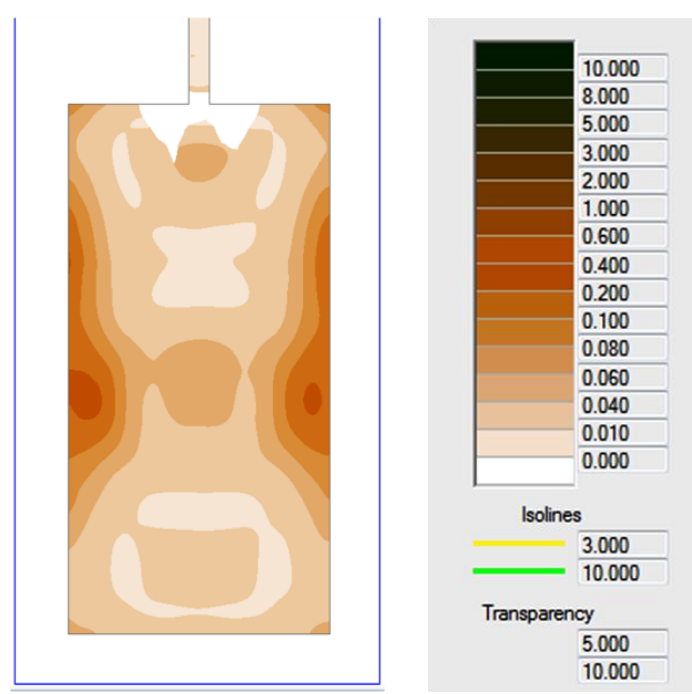

Effective plastic strain, *0.01

Figure 13 - Effective plastic strain of the casting on 261.039 second of the solidification process. 


\begin{tabular}{l|lrl|l|ll} 
& ISRA (India) & $=\mathbf{1 . 3 4 4}$ & SIS (USA) & $=\mathbf{0 . 9 1 2}$ & ICV (Poland) & $=\mathbf{6 . 6 3 0}$ \\
Impact Factor: & ISI (Dubai, UAE) $=\mathbf{0 . 8 2 9}$ & PUHU (Russia) $=\mathbf{0 . 2 3 4}$ & PIF (India) & $=\mathbf{1 . 9 4 0}$ \\
& GIF (Australia) & $\mathbf{0 . 5 6 4}$ & ESJI (KZ) & $=\mathbf{3 . 8 6 0}$ & IBI (India) & $\mathbf{4 . 2 6 0}$
\end{tabular}

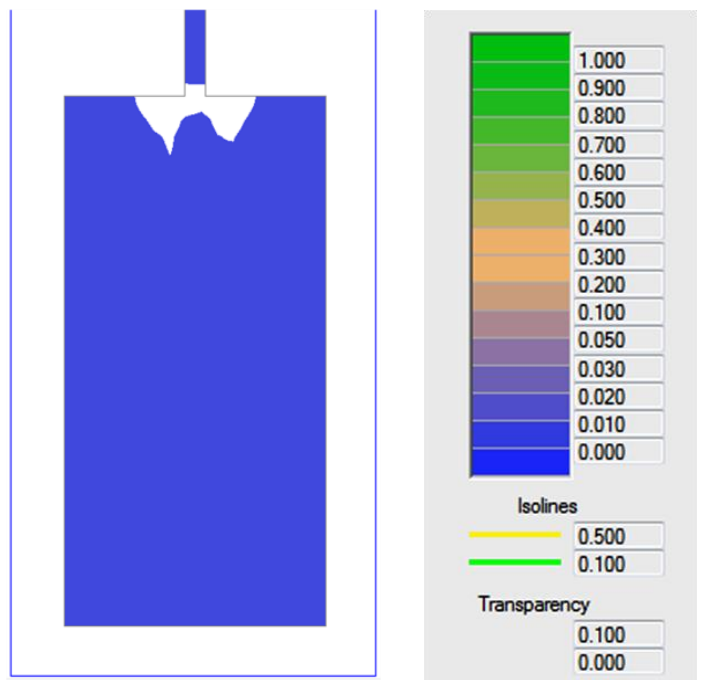

The plastic deforming work, $\mathrm{MPa}$

Figure 14 - The plastic deforming work of the casting on 261.039 second of the solidification process.
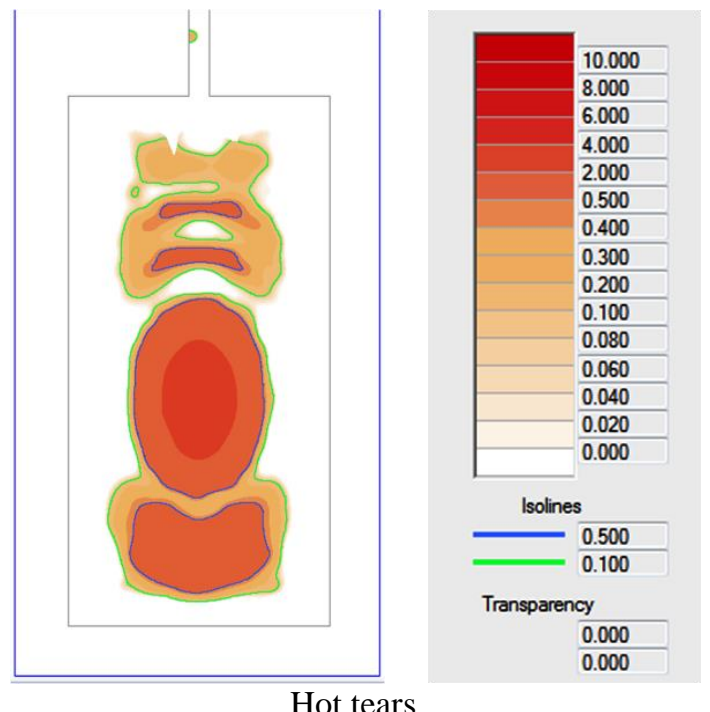

Figure 15 - Hot tears in the casting on 261.039 second of the solidification process.

The predicted elongation of the casting amounts $1-1.35 \mathrm{~mm}$ from the initial length. By the width of the casting, the displacement amounts $0.5 \mathrm{~mm}$. Deviation from the required dimensions of the castings amounts $1 \%$.

Maximal principal stress is concentrated at the center of the casting. The highest value of stress amounts $110 \mathrm{MPa}$. Maximal principal stress of the casting material has the positive value, i.e. it corresponds to the maximum possible for the value of normal stress of the tensile at the point.

The type of deformation of the casting material is determined by median and minimal principal stresses. The surface layers of the casting material are exposed by normal compressive stress (negative values). The inner layers of the casting material are exposed by tensile stress (positive values).
Yield stress is distributed throughout the volume of the casting material. Calculated yield stress of the casting material amounts not more than $200 \mathrm{MPa}$. This means that residual deformation in the material is absent, because calculated yield stress is less than allowable yield stress for steel of the grade $16 \mathrm{MnCr} 5$.

Highest von Mises stress of the material is distributed in the center and by the side surfaces of the casting. From the side of the feeder, the casting material is deformed less.

The positive values on the calculated field of pressure correspond by the tensile isotropic part, the negative values correspond by the compressive isotropic part. The character of pressure of the casting material is similar by to principal stresses.

After solidification of steel, the shape casting slightly changes (the surface layers of the material). 


\begin{tabular}{|c|c|c|c|c|c|c|}
\hline Impact Factor: & $\begin{array}{l}\text { ISRA (India) } \\
\text { ISI (Dubai, UAE } \\
\text { GIF (Australia) } \\
\text { JIF }\end{array}$ & $\begin{array}{l}=1.344 \\
=0.829 \\
=0.564 \\
=1.500\end{array}$ & $\begin{array}{l}\text { SIS (USA) } \\
\text { PИНЦ (Russia) } \\
\text { ESJI (KZ) } \\
\text { SJIF (Morocco) }\end{array}$ & $\begin{array}{l}=0.912 \\
=0.234 \\
=3.860 \\
=\mathbf{2 . 0 3 1}\end{array}$ & $\begin{array}{l}\text { ICV (Poland) } \\
\text { PIF (India) } \\
\text { IBI (India) }\end{array}$ & $\begin{array}{l}=6.630 \\
=1.940 \\
=4.260\end{array}$ \\
\hline
\end{tabular}

This is confirmed on the calculated field of the plastic deforming work of the casting material (value of the plastic deforming work amounts not more than $0.01 \mathrm{MPa}$ ).

Intensity of the formation of hot tears in the casting material depends on the value of maximal normal tensile stress, which during crystallization in the conditions of achievement of the full solidus is acts [8]. Since maximal principal stress in the area of the formation of hot tears has the positive values, it is possible the fracture of the crystal skeleton of the casting. With the increase of the value of normal tensile stresses, the probability of this fracture increases.

\section{Conclusion}

Thus, on the basis of the performed simulation several conclusions can be drawn:

1. Time of cooling (solidification) of the steel ingot when the specified dimensions is approximately of 261 s. Full crystallization of chrome-manganese steel with the formation of maximal residual stresses occurs at the temperature of $180^{\circ} \mathrm{C}$.

2. The solidification process is accompanied by deformation of tension and compression of the material in the inner and outer layers, respectively.

3. Dimensional change of the casting by $1 \%$ after solidification is allowed for this method of the workpiece manufacture.

4. Hot tears in the casting material are concentrated in the inner layers.

\section{References:}

1. (2017) Casting (metalworking). Available: https://en.wikipedia.org/wiki/Casting

(Accessed: 18.05.2017).

2. Cherepanov AN (2006) Thermal and stressdeformation processes in the continuous cast billet of steel. Institute of theoretical and applied mechanics Siberian branch of the Russian Academy of Sciences. Series 1. -47 p.

3. Voronin YuF (2005) Atlas of casting defects. Black alloys. M.: Mechanical engineering - 1. $328 \mathrm{p}$.

4. Sushko TI, Eremin SA, Turischev VV, Pashneva TV (2010) The diagnosis of pouring defects for sand casting by SKM LVM Flow. The Bulletin of Voronezh State Technical University, №12, Vol. 6.

5. Skrebtsov OM, Kuzmin JD, Sekachev OO, Kachikov OS, Terzi VV (2013) The influence of the liquidus temperature of melted steel and heat above it on mechanical properties of metal. The Bulletin of Pryazovskyi State Technical University, 26. - p. $111-116$.

6. (2017) Eutectic. Available: https://ru.wikipedia.org/wiki/Эвтектика

(Accessed: 18.05.2017).

7. Grebenkov SK, Shatsov AA, Skudnov VA, Kleiner LM (2014) Metal science, heat and plastic treatment of metals strengthening of low carbon martensitic steels of system Cr-Mn-NiMo-V-Nb. Transactions of NNSTU n.a. R.E. Alekseev, №3. - p. 228 - 238.

8. Lohit Kumar B.L.N (2010) Simulation of hot tears in castings. Submitted in partial fulfillment of the requirements for the degree of Master of Technology. Indian institute of technology Bombay. $-101 \mathrm{p}$. 